MagdalenA RADOMSKA

\title{
TRANSFORMACJA W SZTUCE W POSTKOMUNISTYCZNEJ EUROPIE
}

Jedną $z$ najistotniejszych prac dotykających problemu transformacji ustrojowej jest określona przez Birutè Pankūnaitè mianem emblematycznej dla sztuki litewskiej w latach 90. ${ }^{1}$ praca Eglè Rakauskaité Pułapka. Wygnanie $z$ raju (il. 1) z roku 1995, która jednak - co symptomatyczne - rzadko, o ile w ogóle, interpretowana jest w tych kategoriach. Dostępna jest w formie rejestracji wideo tego, co w literaturze przedmiotu określa się mianem żywej rzeźby, gdyż - jak wskazuje Gabija Purlytè - termin performance nie był jeszcze w tym czasie w użyciu na Litwie ${ }^{2}$. W pracy wzięło udział trzynaście młodych dziewczyn, których włosy zaplecione w warkocze Rakauskaite związała tak, iż każda próba ich oddalenia się od siebie lub rozdzielenia wiązała się z odczuwaniem przez nie bólu. Przyodziane w białe szaty i żołnierskie płaszcze dziewczyny ustawiła artystka tyłem do siebie, na linii okręgu, i zaopatrzyła w nożyczki, których ostatecznie zmuszone były użyć, by się rozdzielić. Lolita Jablonskienè twierdzi, iż kluczem do zrozumienia pracy jest tytuł serii, na którą składała się ta oraz inna praca artystki, zatytułowana Sieć (1995), w postaci sieci związanych kokardami warkoczy, rozpiętej między dachami budynków w Wilnie - Dla winnych bez winy - Be kaltés kaltiems. Autorka dowodzi związku pomiędzy litewskimi słowami kaltas ('winny') i - powstającym przez zanegowanie go słowem „dziewica” - nekaltas, oznaczającym także człowieka bez winy ${ }^{3}$. Określa ona tę żywą rzeźbę mianem „poezji dziewictwa", operując przy tym poetyckim, niezwiązanym z interpretacją wizu-

${ }^{1}$ G. Purlytè, Egle Rake (Rakauskaitè). A Lithuanian Case Study of Art in the Globalisation Age, <https://www.academia.edu/10321120 Egle_Rake_Rakauskaite_A_Lithuanian_ Case_Study_of_Art_in_the_Globalisation_Age> [dostęp: 22 grudnia 2017].

${ }^{2}$ Ibidem.

${ }^{3}$ L. Jablonskienè, Egle Rakauskaite, w: eadem, Distant Lighthouses, Lissabon 1998, s. 17. 
alną pracy językiem ${ }^{4}$. Jakkolwiek jawią się jako arbitralne, znaczeń tych nie należy całkowicie uchylać. Dla pracy litewskiej artystki kluczowe wydają się jednak nie poszukiwania w materii języka, lecz odwołanie do wizualności, szczególnie dobitnie wybrzmiewające w zestawieniu pracy ze znaną rzeźbą Josepha Chaikova - sowieckiego artysty o ukraińsko-żydowskich korzeniach - zrealizowaną w postaci fontanny Przyjaźń ludów (il. 2). Choć forma rzeźby wydaje się tradycyina - Chaikov zakorzeniony był w środowisku awangardy rosyjskiej, a w roku 1918 wraz z El Lissitzkim założył w Kijowie organizację Kultur Lige, poświęconą upowszechnianiu kultury jidysz w Europie Środkowo-Wschodniej. W latach 20. wykładał w moskiewskim Wchutiemasie kubofuturystyczną rzeźbę u boku takich twórców, jak Wiera Muchina czy Boris Korolev. Moskiewska realizacja przedstawiająca siostrzane republiki radzieckie powstała w roku 1954 na terenie Wszechrosyjskiego Centrum Wystawowego (określanego wtedy mianem Wszechzwiązkowej Wystawy Rolniczej), założonego w roku 1935, a otwartego ponownie po drugiej wojnie światowej w roku 1954. Oryginalny program Centrum powstał przy udziale najwybitniejszych rosyjskich twórców, choćby El Lissitzkiego czy Aleksandra Deineki.

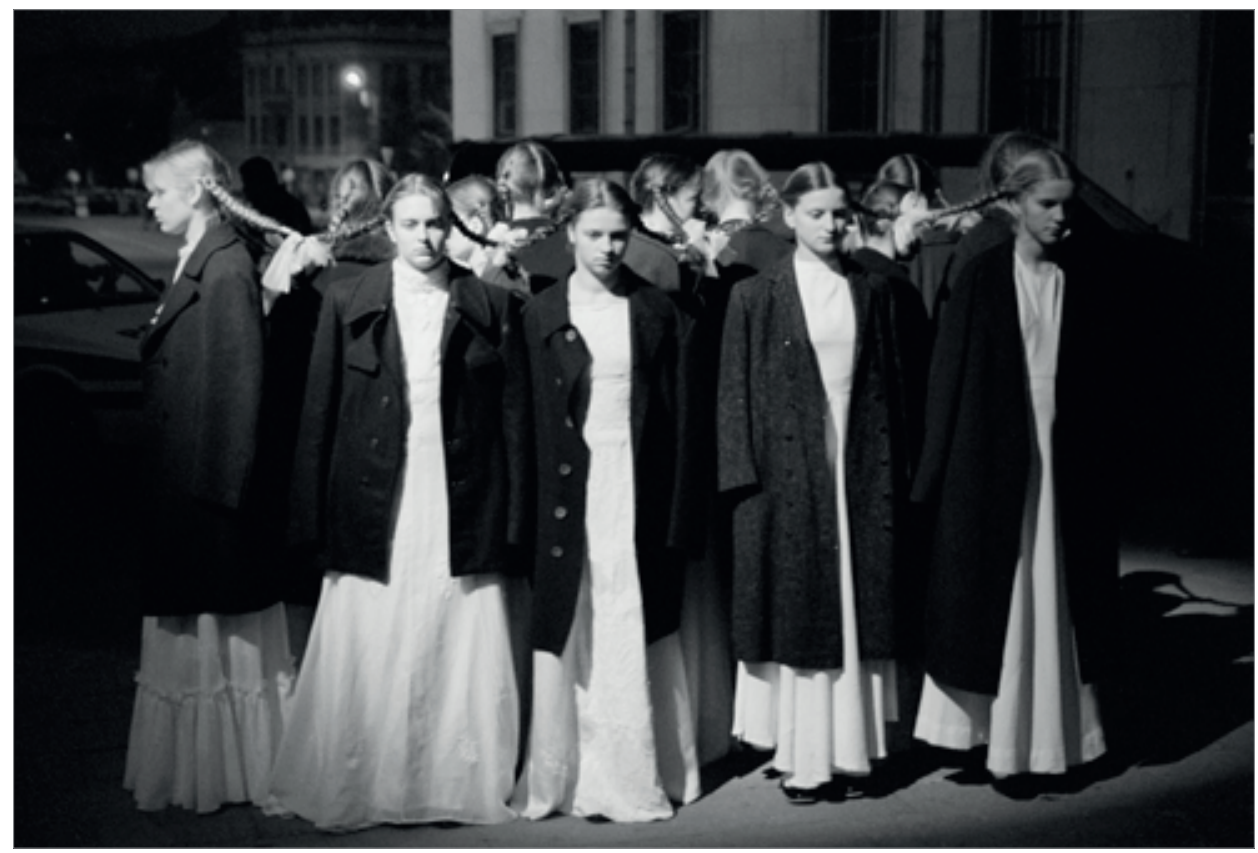

1. Eglè Rakauskaitè, Pułapka. Wygnanie z raju, 1995, wideo. Dzięki uprzejmości artystki

${ }^{4}$ Ibidem. 


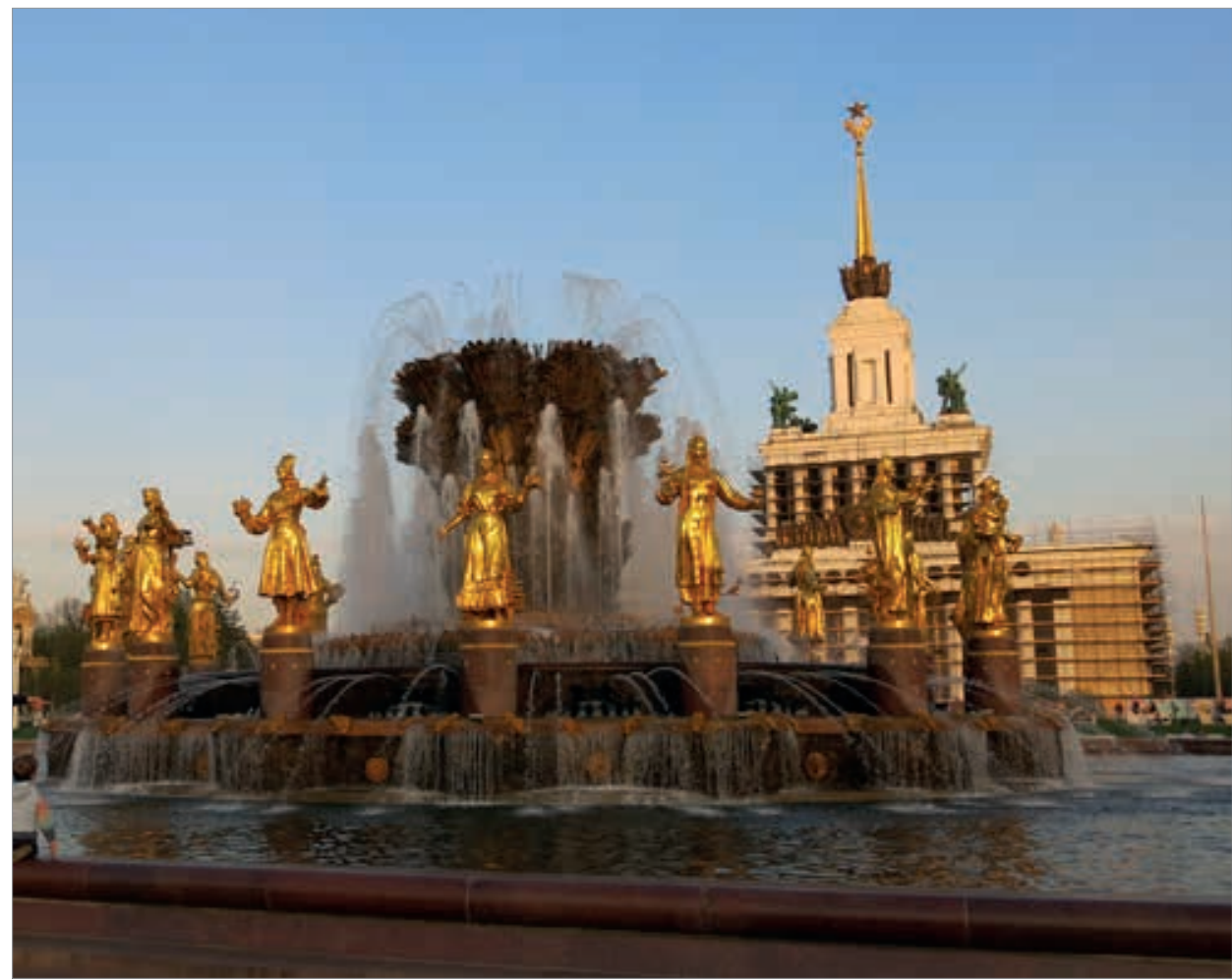

2. Josif Chaikov, Przyjaźń narodów, 1954, fontanna na terenie Ogólnorosyjskiego Centrum Wystawowego, fot. Magdalena Radomska

W projekcie Chaikova zaaranżowane w tanecznym rytmie figury przedstawiają kobiety przyodziane w stroje narodowe charakterystyczne dla poszczególnych republik radzieckich, trzymające plony reprezentatywne dla związanych z nimi obszarów geograficznych. Większość z nich to kobiety uczesane w warkocze, które splatają się z trzymanymi przez nie wiankami i kłosami zbóż, stanowiącymi ponadto centralny motyw fontanny i pojawiającymi się w programie ikonograficznym wystawy ${ }^{5}$. W porządku wizualnym kobiety wiąże zatem figura okręgu oraz motyw kłosów zboża. Praca Rakauskaitė jawi się jako historyczny przypis do pracy Chaikova w postaci uwolnienia przedstawionych kobiet od spajającej je figury i wiążącej się z tym narracji historyczno-politycznej. Ubiór kobiet - żołnierskie płaszcze przykrywające i skrywające białe tuniki - interpretować można tym samym jako formy dyskursywne,

${ }^{5}$ Chodzi tu między innymi o motywy dekoracyjne latarni, które zaprojektowane zostały dla całej przestrzeni Centrum. 
w które przyodziana została narracja unii siostrzanych republik związkowych $-z$ jednej strony unii o znaczeniu militarnym, $z$ drugiej - wspólnej tym krajom komunistycznej utopii.

Interpretacja pracy Rakauskaite wydobywa symptomatyczny problem narracji historyczno-artystycznych powstających w latach 90., a więc w dekadzie ściśle związanej z transformacją ustrojową, którym jest użycie nowego języka - języka, dosłownie i w przenośni - już po transformacji. Skazuje to prace artystów na obszary znaczeniowe generowane za pomocą obowiązujących w poszczególnych krajach praktyk dyskursywnych - sztuki krytycznej w Polsce, feminizmu i sztuki performance w Rosji, postępu technologicznego w Estonii i innych. Pojęcie dziewiczości, które dominuje w interpretacjach pracy Wygnanie z raju, także w tekstach zorientowanych na kontekst polityczny badaczy, takich jak przywołujący te interpretacje Piotr Piotrowski ${ }^{6}$, wydaje się znaczące, odsłania bowiem inklinację dyskursu do konstytuowania się jako powstającego nie w trakcie, lecz w efekcie transformacji ustrojowej, jako nowego języka nowej rzeczywistości. Pojęcie dziewiczości konotuje bowiem nie tylko funkcjonujący wówczas w większości postkomunistycznych krajów dyskurs feministyczny, ale także - nowy świat. W ten sposób praca, której wizualność zdaje się dobitnie problematyzować pojęcie transformacji, staje się raczej świadectwem transformacji dyskursu historyczno-artystycznego. Język ten - zbyt często powstający jako nowy język wobec nowego świata - abstrahował od toczącego się jeszcze przecież w latach 90. procesu transformacji ustrojowej, wtłaczając wizualność prac, które można by przecież interpretować w kontekście transformacji ustrojowej, w obowiązujące wtedy dyskursy takie, jak feminizm. Owa dziewiczość - interpretowana zgodnie $z$ dominującymi w latach 90. narracjami i całkowicie niezgodnie $z$ historyczno-politycznym kontekstem powstania pracy - w kategoriach „stanu sprzed wejścia we władanie patriarchatu", to nic innego jak funkcja utopii nowego, odmienionego i - w tym sensie - „dziewiczego” właśnie języka, który w zamyśle jego twórców miał być zwiastunem przemiany. Język ten - co niezwykle niebezpieczne - często funkcjonował nie w charakterze papierka lakmusowego tejże przemiany, lecz jako jej narzędzie, jawiąc się fałszywie jako właściwy kontekst powstających w tym samym czasie co on prac i zastępując nierzadko kontekst historyczno-polityczny. Dobitnym przykładem jest tu ambiwalentny status dyskursu feministycznego, który - choć zakotwiczony przecież w lewicowych i świadomych kontekstu społecznego tradycjach, w postkomunistycznej Europie stanowił jedną z dominujących narracji, czułych wprawdzie na

${ }^{6}$ P. Piotrowski, Agorafilia. Sztuka i demokracja w postkomunistycznej Europie, Poznań 2010, s. 251. 
pewne aspekty społeczno-politycznej rzeczywistości, utrudniających jednak postrzeganie powstających wtedy prac w nieco inny sposób - w postaci lektury w poprzek operacyjnych narracji, zakotwiczonej w społeczno-politycznej i ekonomicznej rzeczywistości transformacji.

Jeżeli pojęcia dziewiczości można by użyć jako kluczowego dla pracy Rakauskaitè, to w takim sensie, iż białe stroje kobiet, ukryte pod żołnierskimi płaszczami, konotowałyby wolność od dawnych opresyjnych struktur politycznych, okupioną jednak pewną niedojrzałością, którą teoretyk transformacji Boris Buden, autor książki Strefa przejścia. O końcu postkomunizmu, określa jako funkcję cynicznej ideologii tranzycji . „Nigdzie - dowodzi filozof - [...] ideał dojrzałego obywatela nie oddziaływał $z$ tak wielką mocą, jak przy jednym z najważniejszych zadań, jakie towarzyszą transition to democracy - mianowicie przy rozwoju «społeczeństwa obywatelskiego» [...], i to właśnie społeczeństwo obywatelskie w uwolnionych od komunizmu społeczeństwach Europy Wschodniej było podobno wciąż za słabe - żeby nie powiedzieć «W powijakach»-w związku z czym trzeba je było dopiero wychować, wykształcić, "postawić na nogi»" ryczno-politycznego, warunkowany pragnieniem wolności rozumianej jako wolność od przeszłości, pozwala na uruchomienie „metafory dziecinności”, „opresyjnej infantylizacji”, która - jak twierdzi Buden - „okazuje się symptomem nowych relacji panowania" ${ }^{\prime \prime}$. Buden wyraźnie nazywa podmiot dyktujący tę "logikę panowania”, wskazując na fakt, iż „widzowie z Zachodu, nieuczestniczący w rewolucjach z lat 1989-1990”, stali się „właściwymi zwycięzcami”, podczas gdy „z ludzi, którzy z walki o wolność wyszli jako zwycięzcy $[\ldots]$, uczyniono historycznych przegranych"10 . Podobne stanowisko głosi w książce Dreamworld and Catastrophe. The Passing of Mass Utopia in East and West teoretyczka Susan Buck-Morss, pisząc wprost o „upadku Europy Wschodniej w szeroko rozłożone ramiona Zachodu”, wraz z którym to, co „reklamowano jako rewolucję, okazało się być inkorporacją, i to nie do Wspólnoty Europejskiej, ale [...] w globalny system kapitalistyczny"11. Pracę litewskiej artystki można zatem interpretować jako zainicjowanie bolesnego procesu transformacji właśnie, rozumianej jako proces separacji, porzucenia tytułowego raju - utopii o charakterze kolektywnym, umożliwiającego wprawdzie

7 B. Buden, Strefa przejścia, tłum. M. Sutowski, Warszawa 2012, s. 39.

8 Ibidem, s. 38-39.

9 Ibidem, s. 39.

10 Ibidem, s. 40.

11 S. Buck-Morss, Dreamworld and Catastrophe. The Passing of Mass Utopia in East and West, Cambridge, MA, 2010, s. 229. 
zrzucenie za dużych szat totalitarnej propagandy, skazującego jednak na bezbronność wobec hegemonii, która transformację tę zawłaszczyła.

Interpretacja prac takich, jak Wygnanie z raju, które wydają się wybrzmiewać w pełni właśnie w kontekście upadku komunistycznej utopii jako prace problematyzujące transformację ustrojową $\mathrm{w}$ zestawieniu $\mathrm{z}$ interpretacjami funkcjonującymi w literaturze przedmiotu, pozwala dostrzec, jak dalece historyczno-artystyczne narracje $z$ lat 90 . i generowane przez nie pojęcia operacyjne utrwaliły się w języku historii sztuki. Stworzyły one przy tym pozornie jedyny kontekst dla prac, które - szczególnie, gdy widzi się je w szerokim kontekście sztuki lat 90. w postkomunistycznej Europie - zdają się uruchamiać szereg niemieszczących się w tych narracjach pojęć, związanych z kontekstem ekonomicznej i politycznej transformacji. Warto zauważyć, iż ułatwiając abstrahowanie od właściwego kontekstu polityczno-historycznego, narracje te jawią się do pewnego stopnia właśnie jako kalka zwycięskich narracji tworzonych na dominującym ekonomicznie Zachodzie, także i wtedy jeśli - jak dyskurs feministyczny - są wobec opresyjnych struktur krytyczne. Jeśli analiza pracy Rakauskaite pojawia się w tekstach badaczy zachodnich - takich jak tekst Roberta Flecka o symptomatycznym tytule Post-communist Art, opresyjna sytuacja dziewczynek wtłoczona zostaje wprawdzie w modną na Zachodzie narrację tranzytologii, a jednak nawet i wtedy nie jest interpretowana w kontekście transformacji. Fleck widzi w niej raczej opresyjność więżącej dziewczynki tradycyjnie rozumianej kultury, która reprodukuje w pewnym sensie opresyjność tłamszącego indywidualność reżimu komunistycznego ${ }^{12}$. Nawet pozycja taka, jak krytyczne i komparatystyczne omówienie sztuki w Europie po roku 1989 - w postaci książki Piotra Piotrowskiego Agorafilia. Sztuka i demokracja w postkomunistycznej Europie $e^{13}$ - w gruncie rzeczy częściowo, jak w przypadku analizy pracy Rakauskaité, reprodukuje te problemy. Piotrowski w swej książce, operując jako kluczową kategorią demokracji i koncentrując się na procesach demokratyzacji sztuki, nie stawia sobie za cel omówienia biegunów transformacji i nie czyni kluczowym pojęcia tożsamości postkomunistycznej, udostępnia jednak krytycznie skontekstualizowane pole, proponując istotny punkt wyjścia do takich rozważań.

Podobną rolę pełnią - budujące potencjalną ramę metodologiczną dla uwzględniającej kontekst transformacji ustrojowej w szerokim kontekście geograficzno-politycznym Europy Środkowo-Wschodniej - teksty teoretyków

${ }^{12}$ R. Fleck, Post-communist Art, w: Who if not we should at least try to imagine the future of all this?: 7 episodes in (ex)changing Europe, red. M. Hlavajova, J. Winder, Amsterdam 2004, s. 232.

13 Piotrowski, Agorafilia..., passim. 
i filozofów, takich jak Boris Buden, Susan Buck-Morss, Chantal Mouffe, Alexander Kiossev czy Marina Gržinić. Pisane zazwyczaj z pozycji postmarksistowskich, dostarczają one kategorii analitycznych, które uważam za adekwatne narzędzie interpretacyjne dla prac powstałych w okresie transformacji ustrojowej. Umożliwia to taką lekturę prac, która - osadzając je na powrót w kontekście transformacji - stanowić może - co postaram się wykazać w dalszej części tekstu - istotne uzupełnienie funkcjonujących narracji.

\section{BIEGUNY TRANSFORMACJI I UTRACONA REWOLUCJA}

Namysł teoretyczny Budena prowokuje pytanie o problematyzację biegunów transformacji ustrojowej, rozumianych zazwyczaj jako odejście od totalitarnego komunizmu w kierunku liberalnej demokracji, tożsamego $z$ procesami demokratyzacji, urynkowienia i tworzenia społeczeństwa obywatelskiego ${ }^{14}$. Pochodzący z Zagrzebia filozof daje podstawy teoretyczne, pozwalające zakwestionować fałszywe, jak to określa, równanie demokracji i kapitalizmu, wspomagające się równaniem wolności i wolnego rynku ${ }^{15}$, wskazując na fakt, iż środkowo-wschodnio-europejski kapitalizm stał się „jeszcze bardziej kapitalistyczny” niż jego zachodni oryginał, wyzwalając się spod zinstytucjonalizowanych w państwie opiekuńczym form solidarności społecznej, co Buden określa mianem „nędzy doganiania”16. Kluczową kwestią podjętą przez filozofa jest problem rewolucyjnej tożsamości roku 1989, określanej przez niego jako „zapomniana czy wyparta prawda nowoczesnej demokracji, mianowicie jej pierwotnie rewolucyjnego charakteru" ${ }^{\prime 17}$. Interpretowane jako błędne równanie demokracji i kapitalizmu zastępuje więc Buden tezą o wspólnym źródle demokracji i rewolucji, podkreślając, iż po roku 1989 pojęcie rewolucji uległo inflacji1 ${ }^{18}$, służącej zerwaniu jego związku $\mathrm{z}$ rewolucją

${ }^{14}$ Problem ten szerzej dyskutuje opublikowany przez Routledge zbiór tekstów poświęconych temu, co określa się mianem „podejścia transformacyjnego”, a charakteryzowanego przez trzy zasadnicze procesy - „demokratyzacji w kierunku demokracji”, „urynkowienia w kierunku gospodarki rynkowej” oraz „tworzenia społeczeństwa obywatelskiego”, podczas gdy biegun wyjściowy określany jest mianem utożsamianego z komunizmem ustroju totalitarnego, związanego z gospodarką planowaną centralnie, w: Democracy and Enlargement in Post-Communist Europe. The Democratization of the General Public in Fifteen Central and Eastern European Countries 1991-1998, red. Ch.W. Haerpfer, London-New York 2008, s. 1 .

${ }^{15}$ Ibidem, s. 28-31.

16 Ibidem, s. 48.

17 Ibidem, s. 28.

18 Ibidem, s. 29. 
komunistyczną i - potencjalnie - antykapitalistycznym dyskursem ${ }^{19}$. Nieobecność pojęcia rewolucji w narracjach dotyczących transformacji w Europie Środkowo-Wschodniej, czy też jego „wyjaławianie” poprzez dodawanie określeń takich, jak „aksamitna” czy „pomarańczowa”, byłaby w tej perspektywie skutkiem „problemu, jaki liberalno-demokratyczna ideologia ma w związku $z$ ideą rewolucji" ${ }^{20}$. Nieobecność tę - $z$ wyłączeniem sytuacji w Rumunii i częściowo w Czechosłowacji - należałoby zatem wiązać nie tylko ze zdyskredytowaniem pojęcia rewolucji przez system totalitarny, ale także $-z$ istnieniem cenzurującej je hegemonii fałszywego równania. Warto dodać, iż hegemonia ta wiązała się z tym, co określić można mianem transformacji języka, który jednak nie zaistniał jako język transformacji przewartościowujący związane $z$ poprzednim systemem politycznym i pojęciowym hasła, ale jako język będący funkcją stwarzania świata na nowo, abstrahując od tego, co Chantal Mouffe i Ernesto Laclau określają w książce Hegemonia i strategia socjalistyczna mianem demokratycznej rewolucji ${ }^{21}$.

Rewolucyina tożsamość roku 1989 wiązałaby się zatem z zakwestionowaniem silnego statusu kapitalizmu w ramach docelowego bieguna procesu transformacji i jego związków z demokracją. Co więcej - jak dowodzi Buden w artykule The Revolution of 1989. The Past of yet Another Illusion-stwarzałaby ona możliwość pytania o potencjalnie totalitarną naturę bieguna docelowego. Buden kwestionuje baśniową, jako to określa, historię, według której pojęcie totalitaryzmu przypisuje się jednoznacznie do wyjściowego bieguna transformacji ustrojowej ${ }^{22}$. „Zgodnie $\mathrm{z}$ tą bajką - twierdzi - raz na zawsze zostawiliśmy totalitaryzm za sobą, nie da się pomyśleć alternatywy wobec naszego współczesnego sposobu życia, a jedyną możliwą do wyobrażenia sobie przyszłością jest taka, która nieustannie powtarza ten urzeczywistniony sen” $^{23}$. Filozof zapewnia o niemożliwości opowiedzenia innej historii, „nawet jeśli nasze doświadczenie stoi z nią w sprzeczności”24. W tej perspektywie mnogość zjawisk politycznych, ekonomicznych, społecznych i historycznych, pozwalająca na wielokrotne definiowanie zarówno wyjściowego, jak i docelowego bieguna transformacji, podporządkowana zostaje pojedynczej, upraszczającej narracji. „W byłych krajach komunistycznych po 1989 roku -

19 Ibidem, s. 28.

${ }^{20}$ Buden, Strefa przejścia, s. 30.

${ }^{21}$ Ch. Mouffe, E. Laclau, Hegemony and Socialist Strategy. Towards a Radical Democratic Politics, Kindle Edition, poz. 204.

${ }_{22}$ B. Buden, The Revolution of 1989. The Past of yet Another Illusion, w: The Manifesta Decade, red. B. Vanderlinden, E. Filipovic, Cambridge 2005, s. 113.

${ }^{23}$ Ibidem.

${ }^{24}$ Ibidem. 
stwierdza gorzko Buden - zaistniał w gruncie rzeczy pojedynczy proces historyczny, który określić można mianem przywrócenia kapitalizmu"25. Filozof bez ogródek wskazuje na podmiot tej zmiany, którym była - jego zdaniem - „wbrew przewidywaniom zwycięskich liberałów” nie „wolna jednostka dochodzącej do głosu demokracji”, lecz „stara, nagle wybudzona ze swego historycznego snu - naród, który nadał zmianie tej instytucjonalną ramę" ${ }^{\prime 26}$. „Polityczny, prawny, wykonawczy i - nade wszystko - ideologiczny aparat państwa narodowego stanowi dziś - twierdzi - najlepszą gwarancję, że to, co prywatne, nigdy na powrót nie będzie wspólne"27. Stąd docelowy biegun transformacji ustrojowej określają, zdaniem Budena, pojęcia prywatyzacji i narodu, nadające demokracji drugorzędny i instrumentalny status - „niczego więcej niż tylko wymówki dla obu"28. Filozof kwestionuje także samą strzałkę transformacji, utożsamianą z ruchem progresywnym. „Ten historyczny krok w przód - dowodzi - w kierunku kapitalizmu i demokracji, był w istocie krokiem wstecz - od Rewolucji Bolszewickiej w październiku 2017 roku, w kierunku rosyjskiej rewolucji burżuazyjnej w lutym tego roku"29. Podobnie, z punktu widzenia podmiotowości politycznej, Buden diagnozuje proces ten jako regres - zwrot od podmiotu klasy robotniczej i rolników oraz związanych z nią rewolucyjnych instytucji do narodu i instytucji państwowych ${ }^{30}$, od koncepcji „międzynarodówki robotniczej z jej emancypacyinym uniwersalizmem”, ku „,[..] nacjonalizmowi i jego roszczeniom, ku wyimaginowanej glorii [...] przeszłości i uświęconemu egoizmowi jej przyszłości"31.

Istotnym, być może najistotniejszym, problemem jest zimnowojenna proweniencja biegunów transformacji ustrojowej. Tę „zimnowojenną, binarną dyskursywną opozycję totalitaryzmu i demokracji" wydobywa i kwestionuje „w samym zalążku” Susan Buck-Morss w książce Dreamworld and Catastrophe. The Passing of Mass Utopia in East and West ${ }^{32}$. Występuje ona przeciwko „standardowej mądrości”, głoszącej, iż „kapitalizm jest pożądaną i nieuchronną, normalną i naturalną organizacją życia społecznego"33. Buck-Morss uchyla uznane zimnowojenne opozycje dyskursywne, w tym także i opozycję socjalizmu i kapitalizmu, wskazując na fakt, iż porażka socjalizmu
25 Ibidem.
${ }^{26}$ Ibidem.
27 Ibidem.
28 Ibidem.
${ }^{29}$ Ibdiem, s. 116.
${ }^{30}$ Ibidem.
${ }^{31}$ Ibidem.
32 Buck-Morss, Dreamworld and Catastrophe, s. XIII.
33 Ibidem. 
wynikała $z$ faktu, iż zbyt wiernie naśladował on kapitalizm ${ }^{34}$. Dopiero zatem uwolnienie dyskursów transformacji od modeli definiowania jej biegunów zakrzepłych w zimnowojennym ładzie pozwala pomyśleć język o transformacji, który nie powstaje jako abstrahujący od przeszłości, ale właśnie dlatego wolny jest od narzucanych przez nią struktur. Pytanie o transformację bowiem, jak słusznie podkreśla w Agorafilii Piotr Piotrowski, wiąże się ściśle z pytaniem o rozpad binarnego zimnowojennego modelu świata ${ }^{35}$. Jest także jednak pytaniem o to, w jakim języku ten rozpad się dyskutuje i w ramach jakiej hegemonii. Jak podkreśla Alexander Kiossev - artyści środkowo-wschodnio-europejscy po okresie kolonizacji kulturalnej i politycznej przez Związek Radziecki dokonali autokolonizacji, uznając fałszywie za opozycyjny dyskurs o proweniencji zachodniej ${ }^{36}$. Z perspektywy wyznaczonej zatem przez bułgarskiego badacza bieguny transformacji określałby zwrot od kolonizacji w kierunku autokolonizacji. Teksty te tworzą możliwą ramę metodologiczną, zdolną przełamać dominację utrwalonych dyskursów historyczno-artystycznych dotyczących sztuki w krajach Europy Środkowo-Wschodniej w latach 90. Warto prześledzić pod tym kątem zasadnicze nurty narracji transformacji, wynikające $z$ analizy pochodzących głównie z lat 90. prac artystów z Europy Środkowo-Wschodniej, problematyzujących pojęcie transformacji ustrojowej.

\section{POSTKOMUNIZM JAKO EKSKREMENT PROCESU TRANSFORMACJI}

Zastosowanie takiej ramy metodologicznej pozwala na zmianę kluczowych pojęć określających tożsamość powstającej w latach 90. sztuki, a także na określenie jej mianem nie tyle demokratycznej, ile postkomunistycznej. Jedną z kluczowych w tym kontekście prac jest kanoniczna dla sztuki estońskiej lat 90. praca Jaana Toomika 15 maja - 1 czerwca 1992 (il. 3). Składają się na nią odręcznie wypisane listy menu artysty z każdego ze wskazanych tytułem dni. Ich formę odczytać można jako odwołanie się do pamięci wizualnej komunizmu - przypominają bowiem te znane z komunistycznych stołówek. Każdej towarzyszy pierwsza strona dziennika, który ukazał się danego dnia, oraz słoik zawierający ekskrementy artysty. Praca Toomika wpisuje się ironicznie w kontekst dwóch należących do kanonu współczesnej sztuki zachodniej prac - Gówna artysty Pierra Manzoniego oraz Date Paintings On Kawary, które artysta umieszczał w specjalnych pudełkach wyściełanych pierwszą

\footnotetext{
${ }^{34}$ Ibidem, s. XV.

35 Piotrowski, Agorafilia..., s. 45.

${ }^{36}$ A. Kiossev, Otherness, again. Notes on Self-Colonising Cultures, w: After the Wall, red. B. Pejić, Stockholm 1999, s. 115-116.
} 


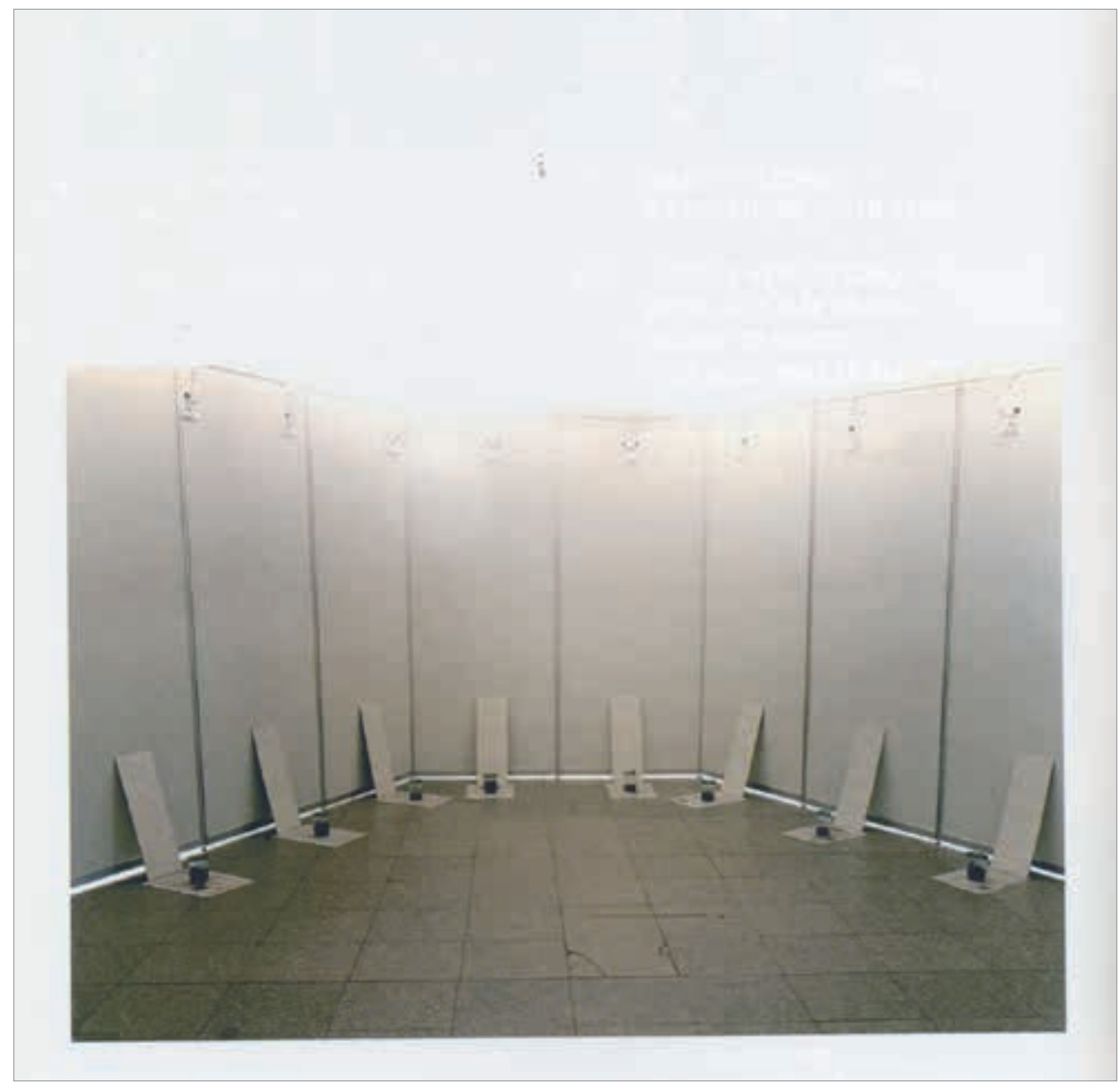

3. Jaan Toomik, 15 maja - 1 czerwca 1992, 1992, instalacja. Dzięki uprzejmości artysty

stroną dziennika z miejsca, w którym powstał dany obraz. Choć zazwyczaj - za sprawą deklaracji samego artysty - praca ta ogólnikowo określana jest mianem nawiązującej do powodujących głód trudnych warunków bytowych w Estonii tuż po transformacji, przed wprowadzeniem waluty lokalnej ${ }^{37}$, interpretować można ją jako jedną z wielu powstających w tym czasie w Europie Środkowo-Wschodniej prac, których tematem jest przyjęcie na własne ciało procesu transformacji. Prace te rzadko wpisywane były w taki właśnie kontekst, funkcjonując raczej w obrębie nurtu sztuki ciała czy dyskursu femi-

${ }^{37}$ H. Soans, Jaan Toomik's nihilist Activism in Post-Soviet Estonia, w: Jaan Toomik, red. H. Soans, Tallin 2007, s. 124. 
nistycznego. Najdobitniejszymi przykładami takich dzieł są prace litewskiej artystki Eglè Rakauskaite W tłuszczu (1998) (il. 4), węgierskiej Kriszty Nagy 200000 Ft (1997) (il. 5) czy bułgarskiego artysty Rassima Krasteva Korekcje 1996-1998 (il. 6). Rakauskaitè leżała zatopiona w przypominającym akwarium pojemniku wypełnionym ciepłym tłuszczem w stanie ciekłym, który w trakcie performance'u artystki stygnąc, zmieniał stan skupienia na stały. Transformację w ujęciu litewskiej artystki można by zatem interpretować jako zmianę stanu skupienia kontekstu, w którym lokuje się podmiot, wizualizowaną za sprawą zmiany stanu skupienia substancji, wypełniającej akwarium. W pracach Nagy i Krasteva transformacja w kierunku kapitalizmu interpretowana była jako opresyjna dla podmiotu i jego ciała. Nagy stworzyła

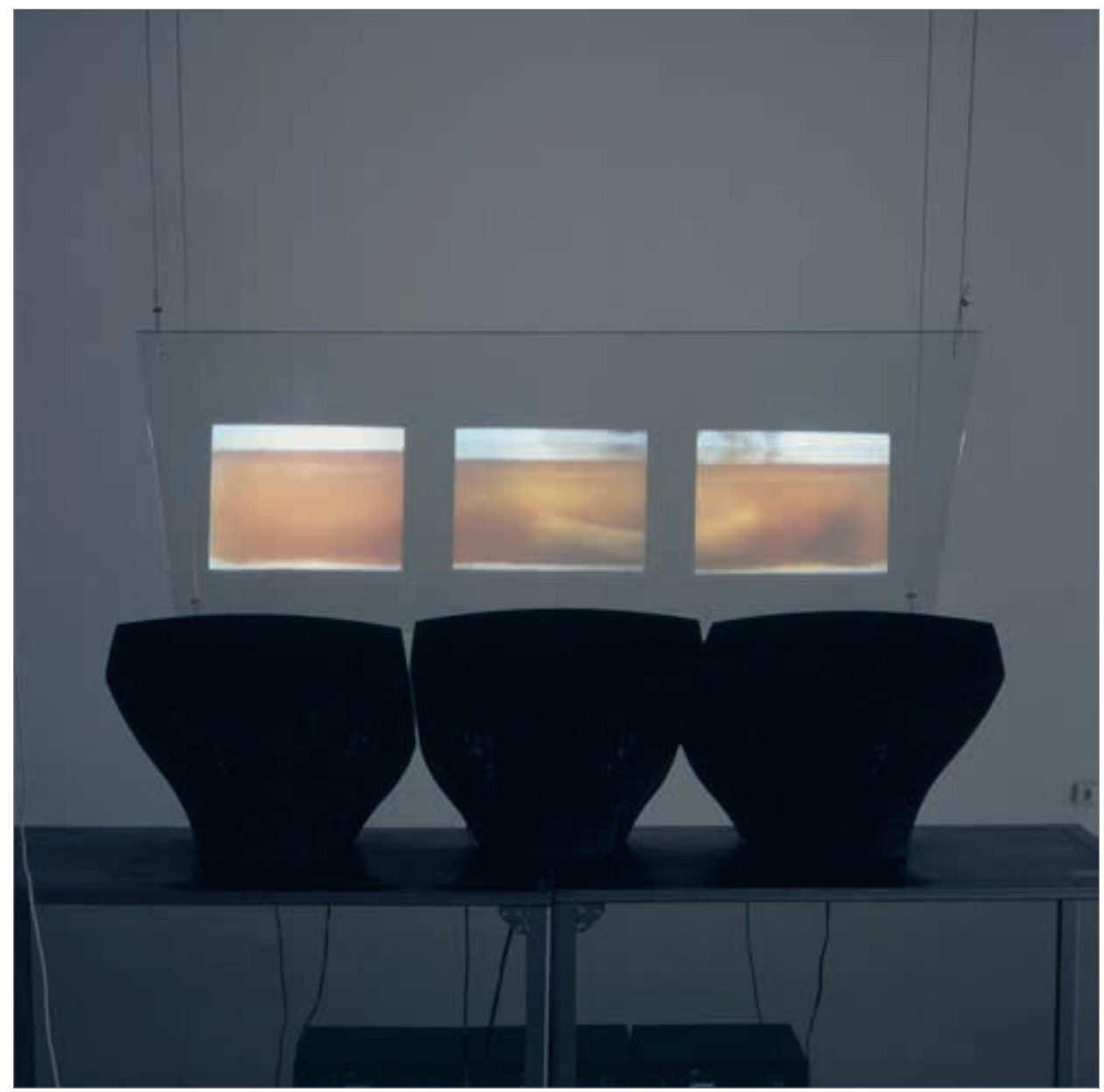

4. Eglè Rakauskaitè, W tłuszczu, 1998, wideoperformans. Dzięki uprzejmości artystki 


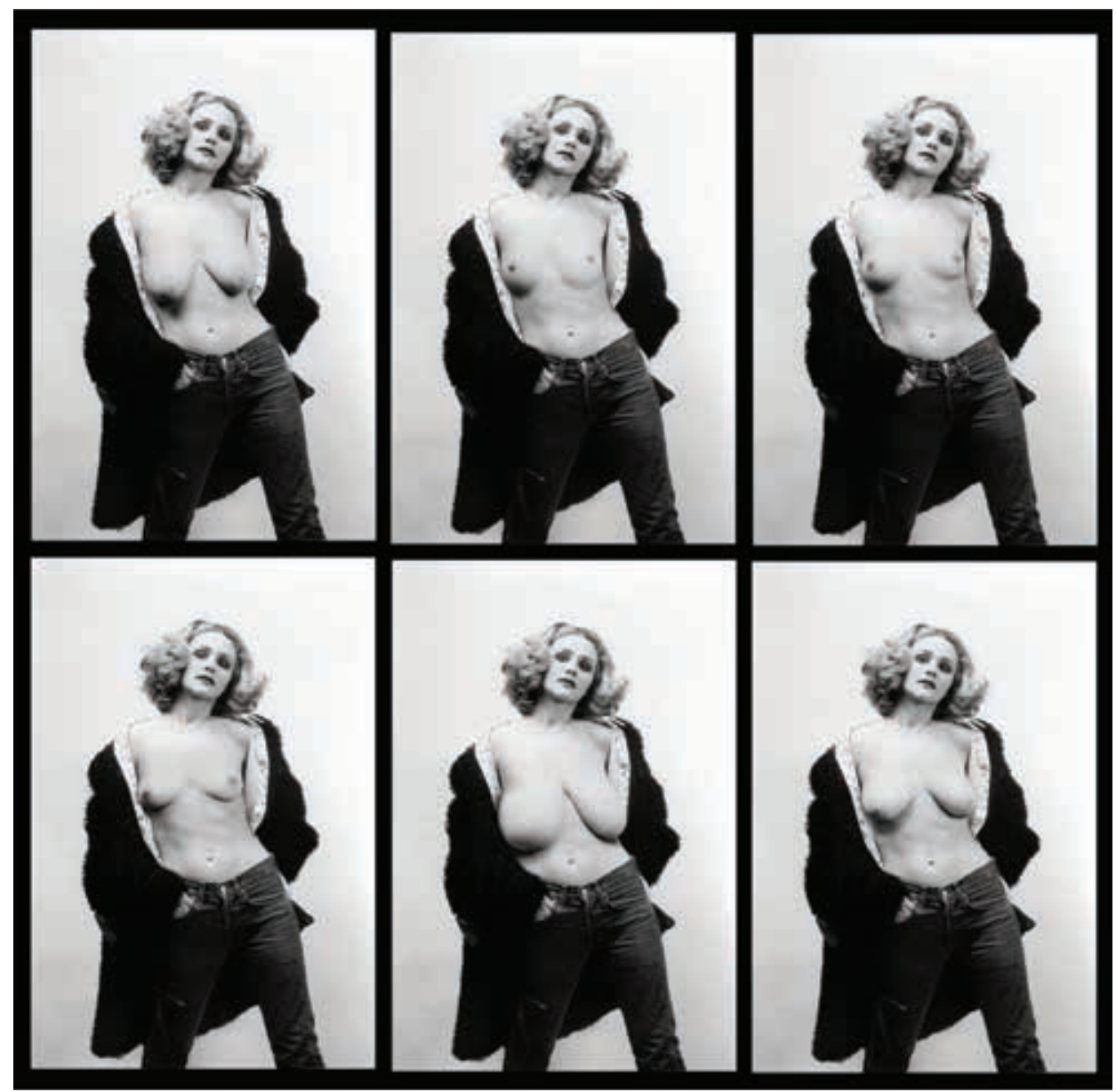

5. Kriszta Nagy, 200000 Ft, 1997, fotomontaż. Dzięki uprzejmości artystki

fotomontaż z własnych zdjęć, prezentujących ją z rozmaitymi wielkościami i rodzajami biustu, będącego w domyśle efektem operacji plastycznej, której cena wynosiła wówczas tytułowe 200000 forintów. Krastev poddał swoje ciało serii ćwiczeń, mających za zadanie zwiększyć jego atrakcyjność, a zatem wpisać je w zachodniej proweniencji paradygmaty hegemonii kapitalizmu. W pracy Toomika transformacja ustrojowa przełożona zostaje na procesy trawienne i zwizualizowana w postaci ekskrementów - ubocznych produktów procesu transformacji ustrojowej. Kwestionuje ona tym samym klarownie wyznaczone bieguny owej transformacji, czyniąc przedmiotem przedstawienia produkt uboczny, niechciany, który interpretować można jako postkomunizm. W książce zatytułowanej Fiction Reconstruced. Eastern Europe, Post- 

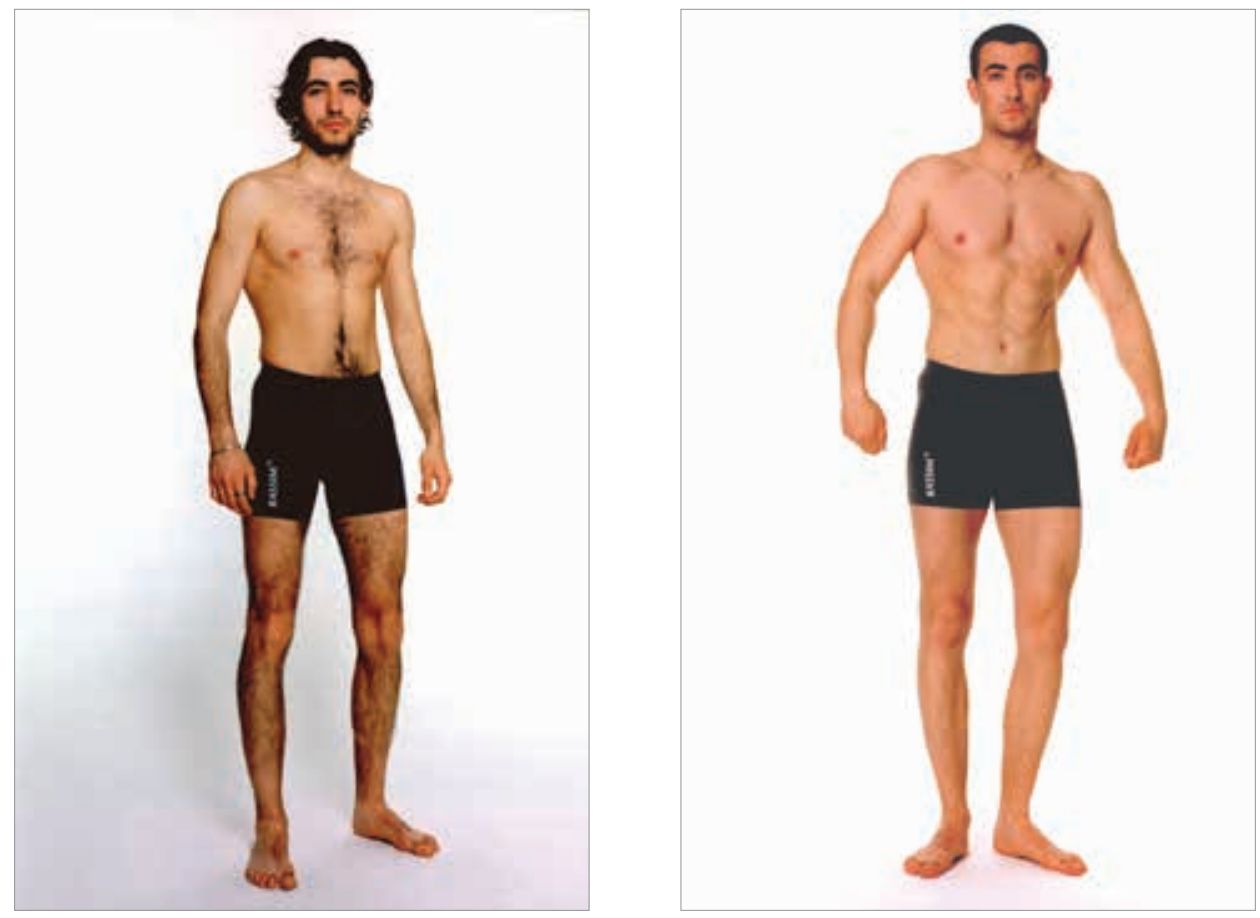

6. Rassim Krastev, Korekcje 1996-1998, Przed, performans / Rassim Krastev Korekcje 1996-1998 - Po, performans, 1996-1998. Dzięki uprzejmości artysty

-Socialism and the Retro-Avant-Garde słoweńska artystka i filozofka Marina Gržinić określała postkomunistyczną Europę Wschodnią mianem naddatku, swoistego ekskrementu Europy i niewystarczająco Europę zarazem ${ }^{38}$. W tej perspektywie teoretycznej nie tylko postkomunistyczna Europa, ale i sztuka, którą można by określić mianem postkomunistycznej, jawi się jako swoisty ekskrement procesu transformacji, rozumianej jako postępowy ruch od totalitarnego komunizmu w kierunku wolnej od totalitarnych inklinacji demokracji wolnorynkowej ${ }^{39}$. Praca Toomika, korzystająca z rozmaitych odniesień, czytelna staje się także w kontekście rozważań Borisa Groysa, który sztukę postkomunistyczną rozumie jako sztukę, która po wydarzeniach historycznych roku 1989 odnosi się do komunistycznej przeszłości i jej języka wizualnego. W tekście Privatizations, or Artificial Paradises of Post-Communist Groys zestawia ją z popularną w latach 90. na Zachodzie sztuką zawłaszcze-

${ }^{38}$ M. Gržinić, Fiction Reconstructed. Eastern Europe, Post-Socialism and the RetroAvant-Garde, Munich 2000, s. 19.

39 Democracy and Enlargement in Post-Communist Europe, passim. 
nia, twierdząc, iż w przeciwieństwie do artystów z krajów zachodnich, którzy w swych „agresywnych i subwersywnych" działaniach problematyzują debatę dotyczącą praw autorskich, sztuka postkomunistyczna dokonuje zawłaszczenia z rezerwuaru „obrazów, symboli i tekstów, które już tak naprawdę do nikogo nie należą i które tym samym nie funkcjonują w intensywnym obiegu, spoczywając raczej [...] na śmietniku historii jako wspólne dziedzictwo $z$ czasów komunizmu" ${ }^{40}$. Groys wskazuje wprawdzie na związane z nią paradoksy, pisząc, iż prywatyzuje ona komunistyczne idee ${ }^{41}$, „utykając ostatecznie w zimnowojennych konfrontacjach" ${ }^{\prime 42}$ - wydaje się jednak, iż taka perspektywa warunkowana jest specyficznym kontekstem namysłu Groysa, którym jest obecna na zachodnim rynku sztuki sztuka rosyjska.

Perspektywa estońska była nieco odmienna od perspektywy większości krajów postkomunistycznej Europy, w tym także rosyjskiej, pozwalającej artystom na zaistnienie na rynku sztuki. Wprawdzie upadek binarnej struktury świata - jak dowodzi Raivo Kelomees - w sztuce estońskiej w latach 90. zinterpretowany został w kategoriach promującej sieci globalnej komunikacji kultury technologii ${ }^{43}$, a zatem $\mathrm{w}$ języku hegemonii kapitalizmu, a rynek estoński rozwijał się niezwykle dynamicznie. Nie miało to jednak przełożenia na ekonomiczną sytuację artystów ani ich afirmatywny stosunek do rynku. Wystarczy przyjrzeć się emblematycznym dla lat 90. pracom, takim jak Looser Kai Kaljo z roku 1997 - w postaci krótkiego wideo-performance'u, podczas którego artystka wygłaszała serię zdań zawierających nieprzystające do nowej rzeczywistości fakty na własny temat ${ }^{44}$. A jednak prace artystów estońskich w kontekście kapitalizacji społeczeństwa były postrzegane jako potencjalna inwestycja - jeden ze słojów Toomika podczas wystawy w roku 1992 został ukradziony. Co zabawne, sytuacja powtórzyła się w trakcie wystawy poświęconej ikonicznym pracom estońskiej sztuki z lat 90. i ich interpretacjom, zatytułowanej MÖH? FUI! ÖAK! OSSA! VAU! w Muzeum Sztuki w Tartu w roku 2012 - jednej z niewielu w postkomunistycznej Europie, którym udało się przewartościować utarte narracje dotyczące sztuki lat 90.

40 B. Groys, Privatizations, or Artificial Paradises of Post-Communist, w: Sustavkoordinata/SystemofCoordinates, red. T. Milovać, Zagreb 2004, s. 30.

${ }^{41}$ Ibidem, s. 32.

42 Ibidem.

${ }^{43}$ E. Kelomees, The Material and the Technological in the Art of the 1990s, w: Noisy Nineties. Problems, Themes and Meanings in Estonian Art on 1990s, red. S. Helme, Tallin 2001, s. 132.

${ }^{44}$ Odnosiły się one na przykład do niskich zarobków artystki, jej wysokiej wagi czy faktu, iż nadal mieszkała $z$ matką. 
Praca Toomika pozostaje w wyraźnym napięciu wobec estońskiego dyskursu historyczno-artystycznego, którego przykładem jest tekst The Myths and the Realities of Post-Communist Art estońskiego krytyka Antsa Juske. Polemicznie odnosząc się do tezy Roberta Flecka, który „stwierdza, że sztukę w latach 90. można podsumować, używając ogólnego określenia «sztuki po komunizmie»"45, oraz Davida Elliota, podtrzymującego kategorię „postkomunizmu”, Juske wskazuje na postkomunistyczną sztukę jako mit - uproszczenie będące funkcją marksistowskiego dyskursu o bazie i nadbudowie $^{46}$. Argumenty, których używa do poparcia swojej tezy, są jednak dość arbitralne. Przytacza on bowiem jako kluczowy argument macedońskiej krytyczki Susany Milevskiej, zakładającej, że określenie sztuki postkomunistyczną implikuje, iż „cała wschodnioeuropejska sztuka przed upadkiem muru berlińskiego była socrealistyczna lub też iż istniało jedynie kilka nisz podziemnego oporu, adekwatnych do osiągnięć zachodnich" ${ }^{47}$. Im bardziej jednak próbuje Juske temu zaprzeczyć, mnożąc przykłady osiągnięć w sztuce komunistycznej Europy „analogicznych wobec sztuki zachodniej”, tym silniej wikła się w hegemonię kultury zachodniej i popada w paradoksy własnego języka. Krytyk (afirmatywnie) używa określeń takich, jak „integracja z zachodnim światem sztuki”, "oficjalne uznanie/rozpoznanie”, "zaawansowanie" ${ }^{\prime 4}$, wskazując za Andą Rottenberg, iż artyści przed rokiem 1989 zachowywali się często tak, jak gdyby komunizm nie istniał, trudno utrzymać zatem pojęcie postkomunizmu zakładającego koniec wielkich utopii związanych $z$ poprzednim ustrojem ${ }^{49}$. To uprzywilejowanie zarówno konstrukcji zachodniocentrycznego dyskursu sztuki i historii sztuki, jak i działalności artystycznej jako miernika aktualności utopii komunistycznych, ciche założenie, że postkomunistyczna sztuka jest sztuką z konieczności po sztuce komunistycznej - a nie taką, która problematyzuje pamięć, także wizualną, przeszłości i korzysta z zaplecza marksistowskiego - jest właśnie funkcją hegemonicznego i opresyjnego dyskursu proweniencji zachodniej. Jak dowodzę - w latach 90. zaistniał on jako wariant owego nowego języka dla nowej rzeczywistości, abstrahującego od tożsamości sztuki uwikłanej przecież w tej części Europy w lewicową tożsamość i język, którym ta operowała.

45 A. Juske, The Myths and the Realities of Post-Communist Art, w: Noisy Nineties..., S. 12 .

${ }^{46}$ Ibidem.

47 Ibidem, s. 13.

48 Ibidem, s. 15.

49 Ibidem, s. 13. 


\section{TRANSFORMACJA JAKO AUTOKOLONIZACJA}

Inną, kluczową pracą artystyczną problematyzującą transformację ustrojową poprzez odniesienie do własnego ciała twórcy była seria działań performatywnych bułgarskiego artysty Rassima Krasteva Korekcje, przeprowadzonych w latach 1996-1998. Medium transformacji uczynił Krastev swoje ciało, które - w serii ćwiczeń na siłowni - poddawał transformacji. Semantykę ciała w kontekście sytuacji politycznej trafnie nakreśla w artykule dotyczącym sztuki ciała w Bułgarii Iara Boubnova. Jak wskazuje - symptomem przemian ustrojowych w Bułgarii - podobnie zresztą jak i w innych krajach postkomunistycznych - były konkursy, „"wychwalane przez media jako symbol zachodniego stylu życia, a także często jako ostateczne wyzwolenie ducha [...] spod ideologii socjalistycznej i prowincjonalnej moralności"50. Zgodnie $z$ diagnozą Boubnovej, kultura masowa funkcjonowała jako narzędzie umożliwiające społeczeństwu zapoznanie się z ludzkim ciałem ${ }^{51}$. Podobnie - w kategoriach ciała poddanego reżimowi kapitalistycznemu - interpretują akcję Krasteva Branislav Dimitrijevic i Branislava Andjelković. Zdaniem badaczy, performance artysty „łączy dwa rodzaje polityki ciała - odnosząc się zarówno do komunistycznego nacisku na aktywność sportową [...], jak i do rodzącej się kapitalistycznej orientacji na centra fitnesu, siłownie i projektowanie ciał jako integralnych części kultury konsumpcyjnej”52 . „Zachodni kapitalizm dowodzą - nie był nigdy tak zorientowany na ciało jak teraz - są w tym nawet - kontynuują - elementy faszystowskie. Ciało zdefiniowano w jego dwoistej roli - ciała, które konsumuje, i ciała, które jest konsumowane" ${ }^{\prime \prime 3}$. Ciało artysty określają jako takie, które podlegać ma konsumpcji, pisząc o nim w kategoriach „kolektywnej fantazji w zgodzie ze zwycięską utopią"54. Autorzy mają tu na myśli wprowadzone przez Susan Buck-Morss rozróżnienie na „wschodnioeuropejską" utopię produkcji i zachodniej proweniencji utopię konsumpcji $^{55}$. Odnotowują oni nie tylko symboliczną, ale także materialną zależność

${ }^{50}$ I. Boubnova, Bulgaria, w: Body and the East. From the 60s to the Present, red. Z. Badovinać, Cambridge 1999, s. 33.

51 Ibidem, s. 35.

52 B. Dimitrijevic, B. Andjelković, The Body, Ideology, Masculinity, and some blind spots in Post-Communism, w: Gender Check. A Reader: Art and Gender in Eastern Europe Since the 1960s, red. B. Pejić, Vienna 2010, s. 240.

53 Ibidem.

${ }^{54}$ Ibidem.

55 Odwołują się oni w przypisie jednak nie do książki Susan Buck-Morss, lecz do jej artykułu: S. Buck-Morss, The City as the Dreamworld and Catastrophe, "October" 73, 1995, s. $127-128$. 
artysty od zachodniego kapitału, wskazując na fakt, iż jego przemiana sponsorowana była przez finansistów francuskich, którzy pokryli koszt konsumowanych przez bułgarskiego artystę protein i witamin ${ }^{56}$.

Warto zauważyć to, o czym nie wspomina Boubnova-iż uwidocznienie nagiego ciała, utożsamiane $z$ wyzwoleniem go z ubrania i tym samym konwencji społecznych, było jedynie pozorne - ciało przyodziane w idiom zachodni stało się w istocie przedmiotem tego, co Alexander Kiossev trafnie określił mianem autokolonizacji ${ }^{57}$.Tak interpretować można Korekcje Krasteva - ukazanie w pracy narzędzi transformacji ciała artysty w postaci sprzętów sportowych maskuje jedynie fakt, iż rzeczywiste narzędzie tej transformacji w postaci idiomu zachodniego staje się tu tożsame ze sposobem widzenia odbiorcy. Praca ta zatem problematyzuje transformację jako proces autokolonizacji narzędziami idiomu zachodniego, a także - jako transformację utopii produkcji, której funkcją była dotykająca ciała propaganda, czyniąca je narzędziem produkcji systemu politycznego, w utopię konsumpcji, w której funkcjonuje ono jako produkt rynkowy. Interpretowana tak praca ukazywałaby zatem proces transformacji jako opresyjny, dotykający bezpośrednio ciała artysty.

\section{BIEGUNY TRANSFORMACJI JAKO FUNKCJA ZIMNEJ WOJNY}

Funkcją potrzeby wielokrotnego definiowania na nowo biegunów transformacji jest legitymizacja binarnej struktury, która wydaje się być silnie osadzona w binarnych formułach zimnowojennego świata i jako taka zdaje się problematycznym narzędziem opisu procesu, w efekcie którego świat ten uległ rozpadowi. Nawet odstąpienie od modelu, w którym wyjściowy biegun transformacji utożsamia się jednym gestem $z$ komunizmem i ustrojem totalitarnym, a docelowy - z tożsamą z wolnym rynkiem demokratyczną wolnością, przecinając tym samym jego związki z tradycją komunizmu i uwalniając go od pojęcia totalitaryzmu - podtrzymuje w gruncie rzeczy stojącą u podstaw tego modelu binarną strukturę znaczeń. Dla problemu tego diagnostyczne jest już samo pojęcie postkomunistycznej Europy, która jawi się jako ekskrement uznanych biegunów transformacji. Częściowo problem ten uchylają poszukiwania w obrębie rzeczowników odczasownikowych, zdolnych zastąpić pojęcie transformacji pojęciami różnymi od tych, które legitymizują ową zimnowojenną strukturę - demokratyzacji, kapitalizacji, tworzenia społeczeństwa obywatelskiego, skutkujące używaniem kwestionujących prawomocność hie-

\footnotetext{
${ }^{56}$ Dimitrijevic, Andjelković, The Body, Ideology..., s. 243.

57 A. Kiossev, Otherness, again..., s. 115-116.
} 
rarchicznej relacji Wschód-Zachód pojęć, takich jak kolonizacja. Nie ujawniają one jednak istoty problemu - faktu, iż transformacja była w swej istocie procesem, który nie dotyczył jedynie tej części Europy i świata, lecz dotykał samej zasady ich podziału.

Jedną z najbardziej oryginalnych propozycji artystycznych zdolnych sprostać temu wyzwaniu jest twórczość bułgarskiego artysty Nedko Solakova. Jego stworzona dokładnie w roku 1989 praca, zatytułowana Widok na Zachód (il. 7), poświęcona jest transformacji jako swoistemu przebiegunowaniu świata i Europy, którą Maria Vassileva określa mianem emblematycznej dla transformacji ${ }^{58}$. Miała ona postać skierowanego na zachód teleskopu umieszczonego na dachu Ulicznej Galerii Shipka $6^{59}$, przez który widać było - niewidoczną gołym okiem - pięcioramienną czerwoną gwiazdę znajdującą się w zwieńczeniu budynku Unii Artystów Bułgarskich, powołanej - jak dowodzi Vassileva - po to, by mogła służyć interesom partii komunistycznej ${ }^{60}$. Praca nie jest po

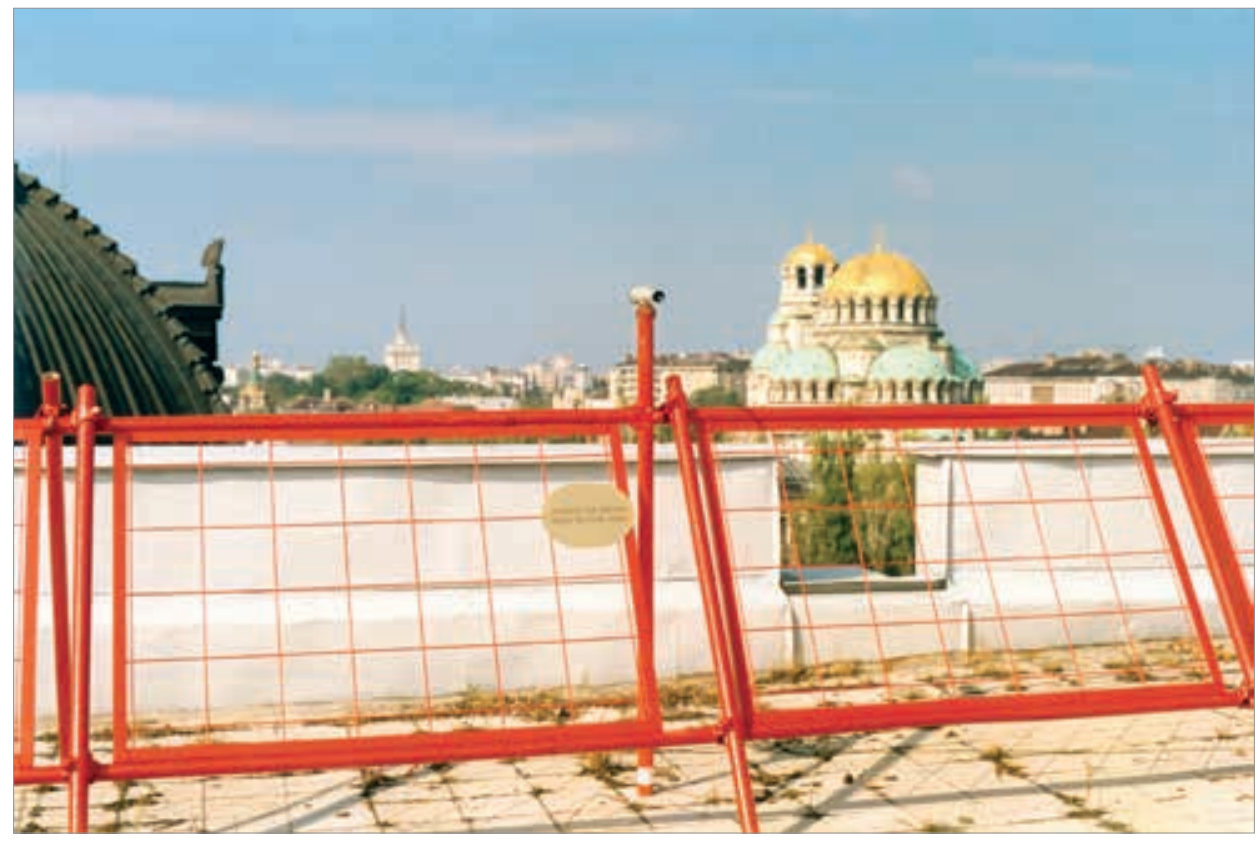

7. Nedko Solakov, Widok na Zachód, 1989, tekst, brązowa tabliczka, teleskop zwrócony na zachód, czerwona gwiazda na szczycie siedziby Bułgarskiej Partii Komunistycznej, Sofia

58 M. Vassileva, Art for Change, w: Art for Change, red. M. Vassileva, Sofia 2015, s. 84.

${ }^{59}$ Wart uwagi jest fakt, iż galeria ta również należała do Unii Artystów Bułgarskich.

${ }^{60}$ Ibidem, s. 81. 
prostu przewrotnym komentarzem relatywizującym binarny zimnowojenny podział świata, odnoszącym się do jego przebiegunowania. Problematyzuje raczej recepcję komunistycznej/postkomunistycznej tożsamości jako tej, która zawarta jest - paradoksalnie - w spojrzeniu skierowanym na Zachód. Problem ten - zawłaszczenia narracji postkomunistycznych przez dyskursy zachodnie jako swoistego zabezpieczenia ich interesów - podejmuje dwóch kluczowych dla sztuki lat 90. krytyków: słoweński, nieżyjący już, kurator Igor Zabel oraz rosyjska historyczka sztuki Ekaterina Degot. W tekście zatytułowanym We and Others Zabel dowodzi, iż posttransformacyjny wariant binarnego układu tożsamości podzielonego zimnowojennego świata („my i inni”) skazuje postkomunistyczną Europę na tożsamość nieesencjonalną i przyznaje jej status the other's other - „inny innego" ${ }^{\prime \prime 1}$. „My" jest bowiem - jak wskazuje historyk sztuki - figurą uprzywilejowaną, zarezerwowaną dla tych, w których władaniu znajduje się język i hegemonia. Podobnie o narracji dotyczącej postkomunistycznej sztuki pisze Degot - jej analiza jednak poświęcona jest casusowi sztuki rosyjskiej, która - choć została dowartościowana w kanonie zachodnim i na rynku sztuki, podlega temu, co autorka nazywa paradoksem podwójnego uwikłania artystów rosyjskich, skazanych na to, by wobec Rosji reprezentować Zachód, a wobec Zachodu - esencjonalnego Innego w postaci dzikiej i nieokrzesanej Rosji ${ }^{62}$.

Określenie sztuki oraz tożsamości tej części Europy jako postkomunistycznej wydaje się problematyczne. Problem ów trafnie podsumowuje Boris Buden, stawiając pytanie o zasadność użycia tego określenia w kontekście geografii politycznej Europy. „Która Europa jest właściwie postkomunistyczna? - pyta. - Ta «stara», która przynajmniej po części trzyma się uparcie socjalistycznego dziedzictwa, czy nowa, która je radykalnie odrzuciła?"63. Buden relatywizuje tym samym nie tylko kategorię zapóźnienia, ale także oryginału i kopii, pytając za słoweńskim socjologiem Rastko Močnikiem, autorem artykułu Will the East's Past be the Wests's Future? o relację Europy Wschodniej i Zachodniej, które jak gdyby zamieniły się miejscami ${ }^{64}$. Problem ten jest istotny, dotyczy bowiem statusu postkomunizmu rozpiętego pomiędzy postrzeganym jako esencjonalne marksistowskim zapleczem i ideą - niezrealizowanej - rewolucji a tym wszystkim, co pojawiło się niejako w jego miejsce, przyjmując postać abstrahujących od niego narracji.

${ }^{61}$ I. Zabel, We and Others, w: After the Wall, s. 110-113.

${ }^{62}$ E. Degot, The Logic of the Absurd: from Dumbness to Idiocy, ibidem, s. 60-61.

${ }_{63}$ Buden, Strefa przejścia..., s. 63.

${ }^{64}$ R. Mocsnik, Will the East's Past be the West's Future? w: Les frontières invisibles, Oostkamp 2009, cyt. za: ibidem. 
Praca Solakova dotykała także jednak i innego problemu - tożsamości totalitarnego komunizmu i totalitarnego kapitalizmu. Takiej interpretacji zdaje się bliska Diana Popova, kiedy pisze o tym, iż „subwersywny potencjał tej pracy brał się ze zwarcia między dwoma ikonicznymi symbolami", wskazując na fakt, iż praca została ocenzurowana przez służby specjalne, które usunęły mosiężną tabliczkę $z$ tytułem pracy ${ }^{65}$. Widok na Zachód jest pracą reprezentatywną dla strategii twórczej Solakova, której zapleczem, jak dowodzę, była dialektyka marksistowska. Strukturyzuje ona właściwie wszystkie prace artysty, począwszy od wielkoformatowych instalacji, jak I miss Socialism, maybe, po drobne prace rysunkowe. Warto przy tym zauważyć, iż twórczość Solakova jest pod tym względem wyjątkowa w sztuce bułgarskiej. Jak dowodzi Alexander Kiossev, bułgarska sztuka z lat 90. przyczyniła się do zaniku komunistycznej sfery wizualnej ${ }^{66}$. Taka interpretacja prac Solakova - jako operujących figurą dialektyki marksistowskiej - otwiera jednak zupełnie nowe perspektywy w dyskursie transformacji, uchylając antytetyczność kluczowych dla niego pojęć.

Podobne znaczenia generuje znacznie późniejsza już praca rosyjskiego artysty Alexandra Kossolapova This is my blood z roku 2001. Choć chciałoby się widzieć ją w charakterze ramy dla dekady $z$ lat 90., w istocie zakotwiczona jest w tradycji wizualnej soc artu - kierunku zrodzonego w latach 70. i dialektycznego na kilku poziomach - nie tylko bowiem funkcjonował on jako swoiste uzgodnienie socrealizmu i pop-artu, ale także obejmował artystów podróżujących między Moskwą i Nowym Jorkiem. Praca powstała jako część swoistego dyptyku $z$ drugą - This is my Body (2001) przedstawia ikoniczny wizerunek Chrystusa na czerwonym tle $z$ logo coca-coli i z wykonanym inną czcionką podpisem - "This is my blood”. W tekście współczesnym pracy Boris Groys zwraca - wobec kontrowersji, jakie ona wywołała - uwagę na fakt, iż sztuce tradycyjnie przypisana jest funkcja profanacji ${ }^{67}$. Dowodzi on ponadto - w sposób dość arbitralny - iż w pracy Kossolapova Chrystus pełni funkcję symbolu władzy kupującej masy, w przeciwieństwie do Lenina, który funkcjonuje jako władza masy te produkująca, wskazując przy tym na komunię jako „prymarną formę konsumpcji masowej” ${ }^{\prime 6}$. Wydaje się jednak, iż dopiero umieszczona w kontekście transformacji praca ta wybrzmiewa w pełni. Przeistoczenie, którego w istocie dotyczy, interpretować można jako figurę

65 D. Popova, Contemporary Art: Communication and Community, w: Art for Change..., s. 138.

66 A. Kiossev, Art-Morphoses 1989-2014. Contemporary Bulgarian Art in Relation to the Changing Political and Visual Context, ibidem, s. 358.

67 B. Groys, History Becomes Form, Cambridge-London 2010, s. 181-182.

${ }^{68}$ Ibidem, s. 185. 
transformacji. Czerwone tło tej szczególnej ikony Kossolapova, które wydaje się wizualizacją zapowiadanej przez tekst pracy przemiany coca-coli w krew Chrystusa, konotuje przecież czerwień jako znak komunizmu. Interpretację taką uprawomocniają liczne prace $z$ dorobku rosyjskiego artysty operujące czerwonym tłem jako symbolem komunizmu właśnie. Szczególnie pochodząca z roku 1980 praca Lenin Coca-Cola. It is the Real Thing, operująca wizerunkiem Lenina i logo coca-coli, którą można interpretować jako ironiczne wskazanie na podwójną konotację czerwieni - komunizm i kapitalizm. Tak rozumieć należy także i omawianą pracę z roku 2001, ilustrującą nie tyle przeistoczenie esencji kapitalizmu w krew Chrystusa, ile transparentność czerwieni na rozmaite zmienne historycznie znaczenia oraz transformację samego języka sfery symbolicznej. Czerwień interpretowana jako kolor krwi konotuje ponadto także i rewolucję. Istotą pracy Kossolapova jest fakt, iż ta nie wyznacza jednoznacznie biegunów transformacji, umożliwiając raczej ciągłe dialektyczne przepisywanie się przypisanych im pojęć.

\section{ROZPAD BINARNEJ STRUKTURY ŚWIATA}

Na zakończenie warto podjąć w skrócie jeszcze jeden kluczowy dla transformacji wątek - niemalże jednoczesny upadek zimnowojennej binarnej struktury świata w wymiarze politycznym oraz binarnej konstrukcji tożsamości seksualnej. Mam tu na myśli fakt, iż publikacja książki Judith Butler Gender Trouble zbiegła się z historycznym końcem totalitarnego komunizmu w Europie. Opublikowana w roku 1990, książka ta ma status pozycji negującej binarną strukturę tożsamości seksualnej opartej na opozycyjnym podziale na płeć męską i żeńską i związanymi z nimi konstrukcjami i mechanizmami pożądania. Dominujące w okresie transformacji dyskursy władzy rzecz jasna nie funkcjonowały w takiej perspektywie. Przeciwnie - po roku 1989 do głosu doszły, jak wskazują Buden i Piotrowski ${ }^{69}$, konserwatywne siły posługujące się raczej binarnym modelem tożsamości seksualnej. W tym kontekście tym symptomatycznym obrazem transformacji był wyborczy plakat węgierskiej partii Fidesz w pierwszych wolnych wyborach w roku 1990, operujący zestawieniem słynnej fotografii ukazującej bratni pocałunek Gorbaczowa i Honeckera z roku 1986 z fotografią całującej się pary młodych ludzi. Między obiema fotografiami widniał napis: „Tessék választani - Proszę, wybierz!” Druga z fotografii konotowała przyszłość waloryzowaną za pomocą pojęć modności,

69 Buden, The Revolution of 1989..., s. 116; Piotrowski, Agorafilia..., s. 164-165. 
płodności, ale także - wybrzmiewającą w kontekście takiego zestawienia heteroseksualność, rozumianą jako conditio sine qua non owej płodności.

Co ciekawe, to właśnie w środowisku węgierskim funkcjonowało dwóch artystów, których prace i tożsamości stanowią jedne z najciekawszych przykładów problematyzacji transformacji rozumianej jako rozpad binarnej struktury politycznej świata, paralelnej do rozpadu binarnej tożsamości seksualnej - El Kazovsky i Róbert Szabó Benke. Twórczość pierwszego z nich, reprezentatywna dla okresu pieriestrojki, nie miała charakteru politycznego w ścisłym tego słowa znaczeniu, lecz ze względu na tożsamość tego węgierskiego artysty rosyjskiego pochodzenia, który urodził się jako kobieta, nigdy nie przeszedłszy transformacji płciowej - prawnej, operacyjnej czy nawet hormonalnej. Twórczość tego artysty, będąca swoistego rodzaju chybioną, niekompletną transformacją, może być interpretowana jako figura drugiej połowy lat 80. okresu pieriestrojki.

Twórczość węgierskiego artysty Roberta Szabó Benke wpisuje się w proces transformacji na wielu poziomach. Ten homoseksualny, urodzony w Jugosławii, artysta funkcjonuje w podręcznikach sztuki węgierskiej, gdyż już w roku 1991 wyemigrował do Budapesztu, uciekając przed wojną. Decyzję tę interpretować można jako akt przyspieszenia boleśnie przedłużanego przez wojnę w Jugosławii procesu transformacji. Wykonany przez niego w roku 2002 tryptyk fotograficzny Konyi Baba ma postać pojedynczego gestu, za pomocą którego artysta uchyla binarne struktury - zimnowojennego świata oraz tożsamości seksualnej. Symptomatyczny jest fakt, iż praca interpretowana jest wyłącznie w kontekście tożsamości seksualnej artysty - w literaturze przedmiotu wskazuje się, iż Szabó-Benke eksperymentuje $z$ tożsamością, przebierając się za japońską gejszę ${ }^{70}$, nigdzie jednak nie podnosi się kwestii, iż czyni to nie za pomocą japońskich ubrań, lecz ludowych wzorów jugosłowiańskich. Czyni on tym samym przedmiotem transformacji własne ciało i kwestionuje stabilną konstrukcję płciową, ale także - destabilizuje tożsamość narodową i polityczną. Wybór kostiumu japońskiej gejszy jest znaczący. Adekwatnym narzędziem analitycznym są tu pojęcia zaproponowane przez Bojane Pejić - bliskiego i dalekiego Innego. "Daleki” - „rzeczywisty” Inny to, zdaniem Pejić, ten należący do odmiennych ram cywilizacyjnych, „bliski”, „nie-całkiem Inny" - ulokowanym w tych samych ramach cywilizacyjnych, lecz poza centrum, na marginesach kultury europejskiej ${ }^{71}$. Praca węgierskiego artysty problematyzuje „bliskiego Innego" -

70 T. Várnagy, Peace and Progression: Budapest Wunderground, <http://www. c3.hu/ ligal/Pingjao/preface.html> [dostęp: 22 grudnia 2017].

${ }^{71}$ P. Piotrowski, O horyzontalnej historii sztuki, „Artium Quaestiones” 2009, 20, s. 64. 
pozostającego w ramach tego samego kręgu kulturowego, lecz odmiennego kontekstu historycznego i politycznego za pomocą figury "dalekiego" Innego, albowiem - jak dowodzi Pejić - bliski Inny jest zbyt bliski ${ }^{72}$. Analogicznej operacji semantycznej poddaje artysta zastane konstrukcje tożsamości płciowej - przyjmując tożsamość kobiety (dalekiego Innego), by wskazać na bliskiego Innego - homoseksualnego mężczyznę. Podobny wydźwięk ma praca artysty z roku 2003 - Cunyi Yashi, będąca wariantem yin i yang, w którym oba dopełniające się elementy są tego samego koloru. Transformacja w pracach Szabó Benke jawi się jako rezygnacja $z$ binarnych modeli tożsamości - zakwestionowanie ich konstytutywnej dla powstawania znaczeń w kulturze roli. Jest to propozycja o tyle istotna, że dotyczy nie tylko tożsamości po tej stronie żelaznej kurtyny, ale obu jej stron i odpowiada na kryzys pojęciowości praktykowanej dotąd przez Zachód, który - jak wskazuje Edit András - zmuszony do „ponownego naszkicowania mapy świata w relacji do Bloku Wschodniego, nadal stosuje tradycyjne, głęboko zakorzenione kolonialne metody $[\ldots]^{\prime 73}$.

Problem transformacji ustrojowej, choć obecny w pracach artystów wobec niej tworzących, marginalizowany jest w dyskursach funkcjonujących w latach 90. w Europie Środkowo-Wschodniej - takich jak sztuka nowych mediów i technologii w Estonii, sztuka performance'u w Rosji, feminizm na Litwie, sztuka ciała na Węgrzech czy sztuka krytyczna w Polsce. Sposobem na wyrwanie dyskursu artystycznego $z$ lat 90. $z$ własnej autoreferencjalności wydaje się umieszczenie go na powrót w politycznym, społecznym, ekonomicznym i historycznym kontekście transformacji i porównanie jego konstrukcji w szerokiej perspektywie geograficznej. Wielokrotnie wyznaczane i problematyzowane w pracach artystów bieguny wyjściowy i docelowy transformacji wskazują na nieadekwatność biegunów rozpiętych tradycyjnie w zwrocie od totalitarnego komunizmu do utożsamianej z wolnym rynkiem demokracji. Analiza tych prac pozwala na zakwestionowanie pozornej antytetyczności obu biegunów, która wikła proces transformacji w zimnowojenne binarne struktury znaczeń. To nie upadek komunizmu - który w postaci lewicowych inklinacji środowiska artystów z tej części Europy i ich marksistowskiego zaplecza intelektualnego nadal obecny jest w sztuce po roku 1989, był bowiem istotą transformacji - ale właśnie upadek binarnej struktury świata. Tak rozumiana transformacja nie dotyczy jedynie wschodniej części żelaznej kurtyny

72 Ibidem.

${ }^{73}$ E. András, A Painful Farewell to Modernism. Difficulties in the Period of Transition, w: Gender Check..., s. 119-120. 
i funkcjonujących tu pojęć - jej impakt i znaczenie widoczne są wyłącznie - jak dowodzi Piotr Piotrowski - w perspektywie globalnej ${ }^{74}$, która stanowi właściwą ramę dla dyskusji o transformacji ${ }^{75}$.

\section{BIBLIOGRAFIA}

András E., A Painful Farewell to Modernism. Difficulties in the Period of Transition, w: Gender Check. A Reader, red. B. Pejić, Cologne 2010

Buck-Morss S., Dreamworld and Catastrophe. The Passing of Mass Utopia in East and West, Cambridge, MA, 2010

Boubnova I., Bulgaria, w: Body and the East. From the 60s to the Present, red. Z. Badovinać, Cambridge 1999

Buden B., The Revolution of 1989. The Past of yet Another Illusion, w: The Manifesta Decade, red. B. Vanderlinden, E. Filipovic, Cambridge 2005

Buden B., Strefa przejścia, tłum. M. Sutowski, Warszawa 2012

Democracy and Enlargement in Post-Communist Europe. The Democratization of the General Public in Fifteen Central and Eastern European Countries 19911998, red. Ch.W. Haerpfer, London-New York 2008

Dimitrijevic B., Andjelković B., The Body, Ideology, Masculinity, and some blind spots in Post-Communism, w: Gender Check. A Reader, red. B. Pejić, Cologne 2010

Fleck R., Post-communist Art, w: Who if not we should at least try to imagine the future of all this?: 7 episodes in (ex)changing Europe, red. M. Hlavajova, J. Winder, Amsterdam 2004

Groys B., Privatizations, or Artificial Paradises of Post-Communist, w: Sustavkoordinata/SystemofCoordinates, red. T. Milovać, Zagreb 2004

Groys B., History Becomes Form, Cambridge-London 2010

Gržinić M., Fiction Reconstruced. Eastern Europe, Post-Socialism and the Retro-Avant-Garde, Munich 2000

Jablonskienè L., Egle Rakauskaite, w: eadem, Distant Lighthouses, Lissabon 1998

Juske A., The Myths and the Realities of Post-Communist Art, w: Noisy Nineties. Problems, themes and Meanings in Estonian Art on 1990s, red. S. Helme, Tallin 2001

Kelomees E., The Material and the Technological in the Art of the 1990s, w: Noisy Nineties. Problems, themes and Meanings in Estonian Art on 1990s, red. S. Helme, Tallin 2001

Kiossev A., Otherness, again. Notes on Self-Colonising Cultures, w: After the Wall, red. B. Pejić, Stockholm 1999

74 Piotrowski, Agorafilia..., s. 28-29.

75 Tekst ten powstał w wyniku badań przeprowadzonych w ramach projektu badawczego „Transformacja w sztuce w postkomunistycznej Europie” (UMO2014/15/B/HS2/01171) Narodowego Centrum Nauki. 
Kiossev A., Art-Morphoses 1989-2014. Contemporary Bulgarian Art in Relation to the Changing Political and Visual Context, w: Art for Change, red. M. Vassileva, Sofia 2015

Mouffe Ch., Laclau E., Hegemony and Socialist Strategy. Towards a Radical Democratic Politics, Kindle Edition

Piotrowski P., O horyzontalnej historii sztuki, „Artium Qaestiones” 2009, 20

Piotrowski P., Agorafilia. Sztuka i demokracja w postkomunistycznej Europie, Poznań 2010

Purlyte G., Egle Rake (Rakauskaitè): A Lithuanian Case Study of Art in the Globalisation Age, <https://www.academia.edu/10321120Egle_Rake_Rakauskaite_A_ Lithuanian_Case_Study_of_Art_in_the_Globalisation_Age > [dostęp: 22 grud̄nia 2017]

Soans H., Jaan Toomik's nihilist Activism in Post-Soviet Estonia, w: Jaan Toomik, red. H. Soans, Tallin 2007

Várnagy T., Peace and Progression: Budapest Wunderground, <http://www.c3.hu/ ligal/Pingjao/preface.html> [dostęp: 22 grudnia 2017]

M. Vassilyeva, Art for Change, w: Art for Change, red. M. Vassilyeva, Sofia 2015

Magdalena Radomska

Instytut Historii Sztuki

Uniwersytet im. Adama Mickiewicza w Poznaniu

\section{TRANSFORMATION IN THE ART OF POST-COMMUNIST EUROPE}

\section{Summary}

The paper focuses on the ways of visualizing political and economic transformation in the works of artists from post-communist Europe mainly in the 1990s. Those works, which today, in a wide geographical context, may be interpreted as problematizing the idea of transformation, were often originally appropriated by such discourses of the post-transformation decade as the art of the new media and technology (Estonia), performance (Russia), feminism (Lithuania), body art (Hungary), and critical art (Poland), which marginalized the problem of transformation. Analyses of the works of artists from Lithuania, Estonia, Hungary, Bulgaria, and Russia make it possible to determine and problematize the poles of transformation in a number of ways, pointing at the inadequacy of those poles which traditionally spread from the end of totalitarian communism to democracy identified with free market economy. By the same token, they allow one to question their apparent antithetical character which connects the transformation process to the binary structures of meaning established in the period of the Cold War. The presented analyses demonstrate that the gist of the transformation was not so much the fall of communism, which is surviving in the post-1989 art of East-Central Europe due to the leftist inclinations of many artists with a Marxist intellectual background, but the collapse of the binary structure of the world. Metho- 
dologically inspired by Boris Buden, Susan Buck-Morss, Marina Gržinić, Edit András, Boris Groys, Alexander Kiossev, and Igor Zabel, they restore the revolutionary character of 1989 and, simultaneously, a dialectical approach to the accepted poles of the transformation. An example of ideological appropriation, which may be interpreted as problematizing the political transformation, is Trap. Expulsion from Paradise by the Lithuanian artist Egle Rakauskaite. The first part of the paper focuses on Jaan Toomik's May 15-June 1, 1992, interpreted in the theoretical terms proposed by Marina Gržinić and Boris Groys as a work of art that visualizes the concept of post-communism as excrement of the transformation process. Placed in the context of such works as In Fat (1998) by Egle Rakauskaite, 200000 Ft (1997) by the Hungarian artist Kriszta Nagy or Corrections (1996-1998) by Rassim Krastev from Bulgaria, Toomik's work is one of many created at that time in East-Central Europe, which thematized the transformation process with reference to the artist's body. Krastev's Corrections problematizes the transformation as a process of self-colonization by the idiom of the West, as well as a modification of the utopia of production, one aspect of which was propaganda referring to the body, changing it in an instrument that transformed the political order into a consumerist utopia where bodies exist as marketable products. The part titled, "The Poles of Transformation as a Function of the Cold War," focuses on A Western View (1989) by the Bulgarian artist Nedko Solakov and This is my blood (2001) by Alexander Kossolapov from Russia. In a theoretical context drawn from the texts by Zabel, Buden, and Ekaterina Degot, Solakov's work has been interpreted as problematizing the transformation understood as refashioning the world, no longer based on the bipolar division into East and West. The paper ends with an analysis of Cunyi Yashi, a work of the Hungarian artist Róbert Szabó Benke, which problematizes the collapse of the bipolar world structure in politics and the binary coding of sexual identity. In Szabó Benke's work, the transformation is represented as rejection of the binary models of identity - as questioning their role in the emergence of meanings in culture.

Keywords:

post-communist Europe, transformation, Marxist dialectic, art of the 1990s, contemporary art 
